\title{
Gender Diversity AS THE ANTIDOTE TO 'GROUPTHINK' ON CORPORATE BOARDS
}

\author{
Akshaya Kamalnath ${ }^{*}$
}

Gender diversity on corporate boards has become a point of emphasis, to the exclusion of all other forms of diversity. This paper analyses whether board gender diversity might help boards overcome groupthink (i.e. the failure of board members to consider alternatives to the dominant view when making decisions). This is a significant question because the board is reponsible for governance of the company and groupthink is often cited as a hurdle to effectively performing this role. Thus, the paper first examines the role of the board, board decision-making processes and the problem of groupthink, and subsequently, the potential of gender diversity to overcome groupthink. It concludes that gender diversity on corporate boards might help overcome groupthink so long as the women directors are also independent and bear 'outsider' status. However, other forms of diversity like race, education, tenure, professional background etcetera might offer the same benefits and thus should not be overlooked.

\section{INTRODUCTION}

Board gender diversity has become a popular idea since the global financial crisis. The main argument is that company boards, which are mostly homogenous, need to be more diverse to ensure that boards make better decisions. As former board member of Citigroup, Sallie Krawcheck, recently said, 'had we had more diversity of thought, perspective, education, gender, colour, the crisis would have been less severe'. ${ }^{1}$

The emphasis on gender diversity has narrowed the focus to ensuring that there is a mix of men and women on company boards. Many countries, including Australia, have introduced regulations in this regard. These regulations have mostly been justified with a mix of different policy rationales. The two dominant rationales are that gender diversity furthers gender equality, and that

\footnotetext{
* Lecturer, Deakin Law School, Melbourne.

${ }^{1}$ Aimee Picchi, 'Wall Street's Sallie Krawcheck has a Message about Diversity' CBS News (online), 30 January $2017<$ https://www.cbsnews.com/news/wall-street-sallie-krawcheck-lackof-diversity-fueled-crisis/>.
} 
it is profitable for businesses to have more women on their boards. The equality rationale for introducing laws to ensure more women directors on corporate boards is, in essence, that in an equal society, positions of power such as board membership, must be equally accessible to both genders. ${ }^{2}$ The business rationale, or the business case, as it is popularly known, canvasses that board gender diversity is beneficial for companies. It attempts to show that board gender diversity results in increased shareholder value. ${ }^{3}$ While each of these rationales have some merit and are worth exploring, it is not the aim of this paper to do so. Instead, this paper examines how diversity and more specifically, gender diversity, might make boards more effectively fulfil their role within the corporation. Thus, it attempts to analyse whether board gender diversity might be the antidote to 'groupthink' in boards, thus making them more effective.

In Australia, the Australian Stock Exchange Corporate Governance Principles and Recommendations (ASX CGPR), introduced recommendations on board gender diversity, in 2010 and subsequently revised them in $2014 .^{4}$ The ASX Listing Rules require that all companies listed on the ASX must provide a statement in their annual report regarding the extent to which these recommendations have been complied with and where they have not been complied with, the statement must explain why this is the case. ${ }^{5}$ However, the rationale for such measures in Australia, like in many other jurisdictions, remains vague and lacks adequate detail. The ASX CGPR very briefly mentions the rationale for the introduction of gender diversity provisions. It cites studies which show a correlation between board gender diversity and financial performance. It also suggests that the promotion of gender diversity widens the pool of candidates considered for board positions. Finally, it states that promoting gender diversity could result in enhanced reputation for the company along with ensuring a closer connection with customers. ${ }^{6}$ While there is some merit in each of the above arguments, none of them speak directly to the most important role of the board of directors within a corporation: corporate governance. It is the effect of board gender diversity on this critical function of the board that needs to be outlined in more detail for both companies and shareholders to be incentivised to petition for gender diversity.

This paper analyses if, and how, board gender diversity might help boards work more effectively. It does so by first examining the role of the board, board decision-making processes and the problem of groupthink, and subsequently, the potential of gender diversity to overcome groupthink. The concept of groupthink (i.e. the failure of board members to be able to consider alternatives

2 See eg, Julie Suk, 'Gender Parity and State Legitimacy: From Public Office to Corporate Boards' (2012) 10(2) International Journal of Constitutional Law, 449.

${ }^{3}$ For a comprehensive review of studies canvassing the business case, see Deborah $\mathrm{H}$ Rhode and Amanda K Packel, 'Diversity on Corporate Boards: How Much Difference Does Difference Make?' (2014) 39(2) Delaware Journal of Corporate Law 377; Sandeep Gopalan and Katherine Watson, An Agency Theoretical Approach to Corporate Board Diversity, San Diego Law Review, 1-72 (2015).

4 ASX Corporate Governance Council, Corporate Governance Principles and Recommendations, $2^{\text {nd }}$ ed, Australian Securities Exchange, 2010; ASX Corporate Governance Council, Corporate Governance Principles and Recommendations, $3^{\text {rd }}$ ed, Australian Securities Exchange, 27 March 2014.

${ }^{5}$ Australian Securities Exchange, Listing Rules (July 2015) r 4.10.3.

${ }^{6}$ Ibid 11. 
to the dominant view when making decisions) draws from psychology and its use by corporate scholars and policy makers is still in its infancy. This paper offers a significant contribution to board gender diversity scholarship by presenting a detailed examination of groupthink in the context of corporate boards. Another contribution of this paper is its focus on the policy rationale that correlates with the corporate boards' most significant role as an instrument of governance.

This paper begins by examining the role of the corporate board in large public listed companies (Section II). Section III focuses on board decision-making processes and the possible effects of the board's composition on the quality of decision-making. Section IV explores the concept of groupthink and its applicability to company boards. Section V considers how board diversity might help overcome groupthink, thus strengthening the board's monitoring role. The final section is the conclusion which canvasses the idea that other forms of diversity might also benefit boards, and contends that there is a need to widen the board diversity debate to include other forms of diversity.

\section{THE CORPORATE BOARD}

The contentious nature of the board gender diversity debate is better understood with an analysis of the theoretical foundations underpinning company law. For instance, a recent bill proposing quotas for women on the boards of Swedish companies was opposed on the grounds that 'mandatory gender quotas are an unacceptable interference with ownership rights. ${ }^{7}$ Similar arguments against board gender quotas have been made in most other countries. Thus, the notion that shareholders are the owners of the company is deeply ingrained in our understanding of the corporation, despite the fact that there are competing theories. ${ }^{8}$ Accordingly, much of the literature seeking to promote board gender diversity attempts to appeal to the 'corporation as property of shareholders' conception by examining the effect of women directors on the profitability of the company. However, the question that must be asked is whether the board of directors in the modern company should be directly involved in generating profits. It would be more pertinent to understand what the corporate board is legally required to do and how it is done, in other words, the function of the board and board processes.

The board of directors is the centre of corporate governance with corporations being managed 'by and under the direction of' the board of directors. ${ }^{9}$ The term 'corporate governance' has been defined as the system by which companies are

\footnotetext{
${ }^{7}$ This was the opinion of Anne Wigart, the legal representative of the Confederation of Swedish Enterprise. Olivier Hoslet, 'Swedish Opposition Blocks Gender Quota Bill for Company Board' New Europe (Online) 16 January $2017<$ https://www.neweurope.eu/article/swedishopposition-blocks-gender-quota-bill-company-boards/>.

${ }^{8}$ The stakeholder theory is the most important competing theory. See, eg Kent Greenfield, The Failure of Corporate Law (The University of Chicago Press, 2006) 127.

9 Jonathan R Macey, Corporate Governance: Promises Kept, Promises Broken (Princeton University Press, 2008) 51. Most countries' corporate legislation now has similar language about the corporations being managed 'by and under the direction of' the board of directors.
} 
governed and controlled. ${ }^{10}$ The board of directors is central to the functioning of the company and the functions they are meant to perform can largely be understood under the three headings of strategy, monitoring and providing access to networks. The OECD Principles of Corporate Governance, published in 2004, briefly states that the role of the board is to provide strategic guidance to the company, to be an effective monitor of the management, and to be accountable to the company and its shareholders. ${ }^{11}$

However, our conception of the role and functions of the board of directors has evolved over time. The historic role of directors was to 'manage'. As large corporations with dispersed shareholders became the norm, the role of the board of directors slowly evolved into 'oversight', that is the hiring and firing, supervision and compensation of officers appointed with the specific task of management. ${ }^{12}$ This shift still allowed the board to engage with questions of strategy and to act as a sounding board for the CEO and other senior management. ${ }^{13}$ Today, the main function of the board of directors is still oversight or monitoring of management, although contemporary boards also tend to be involved in broad policy issues and in networking. ${ }^{14}$

\section{A Monitoring}

The theoretical basis for the monitoring role of the board is provided by agency theory, which, in turn, is informed by shareholder primacy theory. One defining feature of the modern corporation, as identified by Berle and Means, is the separation of ownership and control. ${ }^{15}$ In other words, where shareholders, who own equity in the company, tend to be comprised of a large number of widely dispersed individuals who are distinct from the executives or managers in control of the corporation. Agency theory is premised on the idea that this separation gave rise to agency problems since the principals (shareholders) are not in a position to directly oversee the agents (managers) in order to ensure that they are acting in the principals' best interests. More specifically, costs (i.e. agency costs) would be involved in ensuring that agents acted in the principals' best interests. ${ }^{16}$ According to Hansmann and Kraakman, one of the main purposes of corporate law is to address the agency problems present in a corporation. They suggest that the agency problem in the corporate setting arises because the agent (manager) has more information about the governance issues than the principal (shareholders). Given this information asymmetry, the principal cannot ensure that the agent's performance was exactly what was agreed upon without cost. Thus, the agent has an incentive to not perform

${ }^{10}$ Cadbury Committee, The Financial Aspects of Corporate Governance (Report, 1992) 2.5, 3.4.

${ }^{11}$ OECD, Principles of Corporate Governance (OECD, 2004) Article VI.

12 John Farrar, Corporate Governance: Theories, Principles and Practice (Oxford University Press, 2008) 92.

${ }^{13}$ Donald C Langevoort, 'The Human Nature of Corporate Boards: Law, Norms and the Unintended consequences of Independence and Accountability' in Thomas W Joo (ed), Corporate Governance: Theory and Policy (Carolina Academic Press, 2004), 338, 339.

${ }^{14}$ Stephen M Bainbridge and M Todd Henderson, 'Boards-R-Us' (Research paper No. 13-11, UCLA School of Law, Law-Econ Research Papers), 1061.

15 Adolf A Berle and Gardiner Means, The Modern Corporation and Private Property (Transaction Publishers, 1932).

${ }^{16}$ Michael C Jensen and William H Meckling, 'Theory of the Firm: Managerial Behaviour, Agency Costs and Ownership Structure' (1976) 3 The Journal of Financial Economics 308. 
optimally or to divert to himself/herself what was promised to the principal. ${ }^{17}$ The board of directors is one mechanism through which agency costs are mitigated. ${ }^{18}$ Thus, since agency theory views shareholders as the owners and hence aims to address the agency problems that would disadvantage shareholders, it can be considered an extension of the shareholder primacy and the nexus of contracts models of the corporation. ${ }^{19}$

The emphasis on the monitoring role of the board can be traced back to Melvin Eisenberg's model for reform in $1976 .{ }^{20}$ His proposal came in the wake of opposition at the time, to corporate practices relating to the Vietnam War, environmental protection, occupational safety and equal employment. A number of corporate collapses also put the spotlight on corporate boards and many studies indicated that boards were no longer able to check CEO power. ${ }^{21}$ In fact, some of the issues identified by these studies are still considered pertinent today. Such studies suggested that outside directors were not effective monitors since they were usually chosen from the same social networks as top executives and since they were likely to be sitting with them on other companies' boards. This familiarity made it unlikely that so-called outside directors would challenge the decisions of top executives. ${ }^{22}$ Further, in a landmark study by Mace, a majority of interviewees indicated that director 'prestige' was the main criteria on which selection of outside directors was based..$^{23}$ The study also found that directors simply did not meet often enough, and that relevant information was often not circulated to the board before board meetings. ${ }^{24}$

At the time, the corporations' statute in each state in the US and many other countries provided that the role of the board was to manage the corporation. However, Eisenberg, in his famous book, The Structure of the Corporation, explained the difference between provisions in law and what tended to happen in practice. At the time, corporations had become such large entities that in practice, the board of directors could not manage the day-to-day operations, especially when the board was largely comprised of non-executive directors. Instead it was the executives involved in management who initiated policy decisions. The board's role often seemed to be limited to 'receipt and consideration of after-the-fact reports' ${ }^{25}$

\footnotetext{
${ }^{17}$ Henry Hansmann and Reinier Kraakman, The Anatomy of Corporate Law (Oxford University Press, 2004) 21.

${ }^{18}$ Jensen \& Meckling, above n 16.

${ }^{19}$ J Robert Brown and Sandeep Gopalan, Opting Only in: Contractarians, Waiver of Liability Provisions, and the Race to the Bottom, 42 Indiana Law Review 285 (2009).

${ }^{20}$ Melvin A Eisenberg, The Structure of the Corporation: A Legal Analysis (Little Brown \& Co, 1976).

${ }^{21}$ Dalia Tsuk Mitchell, 'The Import of History to Corporate Law', (2015) 59, Saint Louis University Law Journal 688-89; See also Roberta S Karmel, 'The Independent Corporate Board: A Means to What End?' (1984) 52 George Washington Law Review 534, 542.

${ }^{22}$ Karmel, Ibid 534, 542.

23 Joel Seligman, 'A Sheep in Wolf's Clothing: The American Law Institute Principles of Corporate Governance Project' (1987) 55 George Washington Law Review 328-35: citing Miles M Mace, Directors: Myth and Reality (Harvard University Press, 1971).

${ }^{24}$ Ibid 332, 328-35.

${ }^{25}$ Eisenberg, above n 19, 40, 141.
} 
Eisenberg proposed that the board should have a primary monitoring functionwith responsibility for supervising, monitoring and selecting executive management. He also proposed that laws should ensure the effective performance of these functions by the board by making the board independent of the executives whose performance they monitor, and by ensuring that the board receives adequate and objective information to enable it to perform this function. ${ }^{26}$ Based on Eisenberg's and other similar recommendations ${ }^{27}$, the American Law Institute (ALI) in its 1984 proposal sought to enhance the monitoring (or oversight) function of the board..$^{28}$ Ultimately this resulted in a focus on increasing the number of independent directors on the board rather than any substantive changes to directors' duties. ${ }^{29}$

Similar changes took place in the UK as well which is reflected in the Cadbury Report, published in 1992, emphasising the need for non-executive directors to perform a monitoring role. It states that the board of directors is responsible for the governance of the companies where 'governance' is defined as ensuring that boards are responsible for: 'setting the company's strategic aims, providing the leadership to put them into effect, supervising the management of the business and reporting to shareholders on their stewardship'. ${ }^{30}$

To contextualise this for the unitary board system followed in the UK, the Report also distinguished between the different roles of executive and nonexecutive directors. While it could be assumed that executive directors would have detailed knowledge of the business, non-executive directors would bring a broader, alternative view to the company's activities. ${ }^{31}$ Non-executive directors would be responsible for reviewing the performance of the board and of the management; and for taking the lead when potential conflicts of interest arose. ${ }^{32}$ It is worth noting that the Cadbury Report stressed the need for non-executive directors, in line with their duty of reviewing the work of the board and of the management, to make their views known to the chairman. ${ }^{33}$ The Cadbury Report also recommended that non-executive directors should be of such 'calibre and number' that 'their views will carry significant weight in the board's decisions' ${ }^{34}$

In Australia, the 1995 Bosch Committee placed substantial emphasis on monitoring in its long list of board functions. ${ }^{35}$ Following this, the decision in AWA $v$ Daniels ${ }^{36}$ echoed the American realisation that companies had become

\footnotetext{
${ }^{26} \mathrm{Ibid}$.

${ }^{27}$ Mitchell, above n 20, 690.

${ }^{28}$ American Law Institute, Principles of Corporate Governance: Analysis and Recommendations (Tentative draft No. 2, 1984) §3.04.

${ }^{29}$ Mitchell, above n 20, 689, 690 .

${ }^{30}$ Cadbury Report, above n 10, 2.5. See generally, Sandeep Gopalan and Katrina Hogan, 'Ethical Transnational Activity at Home and Abroad: A Proposal for Reforming Continuous Disclosure' 1 (2015) 46 Columbia Human Rights Law Review 16-17, for a discussion of the UK model.

${ }^{31}$ Ibid 4.1

${ }^{32}$ Ibid 4.4.5, 4.6.

${ }^{33}$ Ibid 4.5.

${ }^{34}$ Ibid 4.11 .

${ }^{35}$ Farrar, above n 12, 351 citing H Bosch (ed) Corporate Practices and Conduct (FT Pitman Publishing, Melbourne, 1995) 8-9.

${ }^{36}$ ACSR 7 (1992) 759.
} 
too big to be managed by the board except in relation to 'matters of high policy'. ${ }^{37}$ However, the Hilmer Committee, which published its corporate governance report in 1993, stated that the main functions of the board were monitoring and corporate performance. ${ }^{38}$ The first edition of the ASX Principles of Corporate Governance, speaking to listed companies, provided that the board of directors is responsible for strategic guidance and effective oversight of management. ${ }^{39}$

To reflect the emphasis on the monitoring function of the board of directors, the legislation regulating corporations in most countries currently states that the business of the company is to be managed by or under the direction of the directors. ${ }^{40}$ The phrase 'under the direction of' was a later addition in most of this legislation to reflect this shift in understanding the board's role. In agency costs language, the monitoring of management by independent directors plays an important role in minimising agency costs between managers and shareholders.

What follows from this premise is an assumption that boards with a majority of independent directors increase company performance because of reduced agency costs. However, the results of empirical studies on this issue are contradictory and far from unequivocal. ${ }^{41}$ Some scholars have responded to the contradictory results with the suggestion that 'one size does not fit all', contending that it may not always be necessary to have a majority of independent board directors. ${ }^{42}$ Bhagat and Black suggest that a moderate number of insiders on the board might add value although they add a caveat that their results on this might not be robust. ${ }^{43}$ It could also be argued that company performance is dependent on a number of factors, not merely the board of directors.

The collapse of Enron, WorldCom and other companies during and after 2008 re-opened the debate about board effectiveness. Many companies that collapsed around this time had complied with relevant stock exchange rules which required boards to have a majority of independent directors. Despite this, the boards failed to perform their monitoring role. ${ }^{44}$ While the response after the

${ }^{37}$ Ibid $166-67$.

${ }^{38}$ Frederick G Hilmer, Strictly Boardroom: Improving Governance to Enhance Company Performance (Information Australia, 1998).

39 ASX Corporate Governance Council, Corporate Governance Principles and Recommendations, ed, Australian Securities Exchange, 2003, Principle 1. See generally, Sandeep Gopalan and Katrina Hogan, Ethical Transnational Activity at Home and Abroad: A Proposal for Reforming Continuous Disclosure, 46 Columbia Human Rights Law Review 1 (2015) 15-17.

40 For instance, s 198(A) (1) of the Corporations Act, 2001 (Australia) provides that: 'The business of a company is to be managed by or under the direction of the directors'.

41 See generally Sanjai Bhagat and Bernard Black, 'The Uncertain Relationship between Board Composition and Firm Performance' (1999) 54 Business Lawyer 921 which is a meta-analysis of the many studies on the issue.

${ }^{42}$ Stephen M Bainbridge, The New Corporate Governance in Theory and Practice (Oxford University Press, 2008), 198.

${ }^{43}$ Bhagat and Black, above $\mathrm{n}$ 40, 954, 955.

${ }^{44}$ Marlene A O'Connor, 'The Enron Board: The Perils of Groupthink' (2003) 71 University of Cincinnati Law Review 1233; Erica Beecher-Monas, 'Marrying Diversity and Independence in the Boardroom: Just How Far Have You Come, Baby?' (2007) 86(2) Oregon Law Review 373. 
financial crisis mostly involved tightening 'independence' requirements, board gender diversity is slowly gaining traction as a possible way to strengthen board effectiveness. Section V explores this proposition.

\section{B Broad Managerial Decisions}

Historically, 'managerialism' or the board's managerial functions were emphasised. Under the 'managerialism' theory of the board, the board was seen as part of the managerial structure of the corporation, and consisted mostly of executive directors. Under this model, the main duties of the board included providing advice to the $\mathrm{CEO}$, strategic planning and review of significant corporate transactions, ${ }^{45}$ and it was considered important to have corporate executives familiar with company business and strategies (i.e. not independent directors). ${ }^{46}$ Thus the prominence of independent directors only started with the rise of the monitoring model of the board of directors.

However, as this discussion so far shows, the board's monitoring role has evolved into the most important function of the board. Even under the monitoring model, the board is still required to approve important business decisions and to advise management on broad policy issues. ${ }^{47}$ Further, individual board members often provide advice and guidance to top management on operational and policy issues. ${ }^{48}$

\section{Resources and Networks}

The board also provides access to networks or contacts that the corporation might find beneficial. Relational theory emphasises this role of the corporate board, and provides an alternative to agency and contractual theories of the corporation. ${ }^{49}$ Relational theory posits that the board of directors helps the corporation gain access to essential resources (i.e. information, advice and contacts) ${ }^{50}$ In other words, the corporation utilises board membership to secure resources for the corporation. ${ }^{51}$

${ }^{45}$ Jill E Fisch, 'Corporate Governance: Taking Boards Seriously' (1997) 19 Cardozo Law Review 272.

${ }^{46}$ Ibid 274.

${ }^{47}$ Bainbridge, Corporate Governance after the Financial Crisis (Oxford Scholarship Online, 2012), 46.

${ }^{48}$ Stephen M Bainbridge, 'Director Primacy: The Means and Ends of Corporate Governance' (2002) 97 Northwestern University Law Review 547, 550.

${ }^{49}$ Lynne L Dallas, 'Two Models of Corporate Governance' (1988) 22 University of Michigan Journal of Law Reform 19.

${ }^{50}$ Lynne L Dallas, 'The Relational Board: Three Theories of Corporate Boards of Directors' (1996) 22 Journal of Corporate Law 1, 10.

${ }^{51}$ Dallas, above $\mathrm{n} 48$. 


\section{Board Decision-making Processes ANd COMPOSITION}

This section focuses on board decision-making processes and how board composition might positively or negatively influence the quality of decisionmaking. A crucial aspect to note about boards is that they are not merely an aggregate of individuals but rather a complex group which develops their own culture of decision-making. Therefore, to understand board processes, it is necessary not only to understand individual directors' motivations but also the group's dynamics and motivations. ${ }^{52}$

The rationale for having a group of directors on the corporate board rather than a single individual is that groups often make better decisions than individuals. ${ }^{53}$ Drawing from behavioural economics literature, Bainbridge has summarised the strengths and weaknesses of group decision-making versus individual decisionmaking. While individuals are usually superior to groups when matters of creativity are involved, individuals are also likely to become wedded to their plans and therefore fail to see any flaws that others might identify. This 'overconfidence bias' can be diffused by group decision-making. It follows that groups are superior to individuals at evaluative tasks. This is because group decision-making would presumably check individual overconfidence by providing critical assessment and alternative viewpoints. ${ }^{54}$ This is consistent with the board's role of advising management where required and more importantly monitoring management excesses. The section of the Model Business Corporations Act in the US which deals with meetings of the board of directors explains in the corresponding commentary that 'consultation and exchange of views' is an integral part of the functioning of the board of directors. $^{55}$

The question that arises is what the ideal composition of the board of directors should be, to ensure that the board's role is best fulfilled. As already noted, by the early 1990s, the consensus was that boards should mostly consist of independent directors. When Eisenberg suggested that boards were unable to directly 'manage' the corporation as was expected of them by law at the time, he identified some 'critical constraints', one of which was the composition of the board. In his opinion, it was striking that the typical board at the time 'included persons who were economically or psychologically dependent upon or tied to the corporation's executives particularly its chief executive', ${ }^{56}$ Another problem Eisenberg identified was that executive directors populated most of the board. While executive directors who reported to the CEO could not be expected to disagree or challenge management decisions, Eisenberg noted that even outside directors were not totally independent of the CEO. This was because most outside directors were lawyers, investment bankers or commercial bankers who were also suppliers of services to the corporations on whose boards they sat. The rest of the directors were psychologically tied to the chief

\footnotetext{
${ }^{52}$ Rakesh Khurana, Searching for the Corporate Saviour, 82 (Princeton University Press, 2002).

${ }^{53}$ Bainbridge (2008), above $\mathrm{n} 41,82-94$, citing numerous experimental studies on the issue.

${ }^{54}$ Ibid 97.

${ }^{55}$ Ibid 82.

${ }^{56}$ Eisenberg, above n 19, 144, 145.
} 
executive because they were friends or former colleagues, or sometimes both. ${ }^{57}$ Even if the directors were not financially or psychologically dependent on the $\mathrm{CEO}$, Eisenberg pointed out that the selection process ensured that such directors were not truly independent of the CEO. This was because outside directors at the time were not selected by the board but by the CEO who would invariably consider whether the candidate could be counted on 'not to rock the boat'. Further, the fact that the director owed the CEO his/her appointment was also a factor in ensuring that the director did not challenge the CEO. It was also common for the CEO to fire a director who challenged management decisions. ${ }^{58}$ Ironically, nearly forty years after Eisenberg's book was published, the board composition debate is still very much alive with some of Eisenberg's concerns still being raised by commentators.

In the aftermath of the 2008 financial crisis, one of the key issues of the board composition debate has been board diversity. ${ }^{59}$ While justifications for board gender diversity are many, most business case arguments essentially contend that board gender diversity will make boards more effective. Since the preceding discussion has emphasised the role of the board, an effective board can be understood to be one that effectively monitors management. While board independence has gained acceptance as a remedy for corporate failure, diversity has not gained the same level of acceptance, perhaps because of the plethora of arguments crowding out the emphasis on board effectiveness. ${ }^{60}$

Although most boards by 2008 were dominated by independent directors, the fact that corporate failures like Enron and WorldCom occurred made it obvious that having independent directors was not always effective. Beecher-Monas argues that the problem lay in the way relevant legal rules defined 'independence' which mostly focused on 'financial' independence but not that of 'the mind'. ${ }^{61}$ Many scholars have also pointed out that directors are often socially connected to other directors and CEOs by virtue of their common residence in elite neighbourhoods and membership in social clubs and professional associations. ${ }^{62}$ Even apart from this, arguments have been made that having independent directors serve long terms can also reduce independence since they foster what has been called 'fictive friendships' amongst directors. This sometimes leads to independent directors hesitating to challenge their 'friends' on the board. ${ }^{63}$

\footnotetext{
${ }^{57}$ Ibid 146.

${ }^{58}$ Ibid 146, 147.

${ }^{59}$ Above $\mathrm{n}$ 1. See also 'Lagarde: What If It Had Been Lehman Sisters?' The New York Times (Online) 11 May $2010<$ https://dealbook.nytimes.com/2010/05/11/lagarde-what-if-it-hadbeen-lehman-sisters/? $\mathrm{r}=0>$.

${ }^{60}$ Lisa Broome et. al., 'Dangerous Categories: Narratives of Corporate Board Diversity' (2011) 89 (3) North Carolina Law Review 759.

${ }^{61}$ Beecher-Monas, above $\mathrm{n} 43$.

${ }^{62}$ Khurana, above n $51,82$.

${ }^{63}$ See generally, Yaron Nili, 'The "New Insiders": Rethinking Independent Directors' Tenure' (2016) 68 Hastings Law Journal 97; See also, Donald C Langevoort, 'Selling Hope, Selling Risk: Some Lessons for Law from Behavioral Economics about Stockbrokers and Sophisticated Customers' (1996) 84 California Law Review 627, 654-55. for a discussion of 'fictive friendships'.
} 
Recalling that the rationale for independent directors is to attempt to ensure that the board critically evaluate management actions, offer diverse viewpoints and actively discuss alternative factual inferences and plans of action, BeecherMonas suggests that a diverse board might facilitate this. ${ }^{64}$ Indeed, according to a recent study by Aaron Dhir, some of the outcomes of the gender quota legislation in Norway were improved dialogue in the boardroom, better decision- making, more effective risk mitigation and crisis management, and higher quality monitoring of and guidance to management. ${ }^{65}$ The argument about board diversity resulting in more active boards usually draws from theories of social psychology particularly that of 'groupthink' applicable to group decision-making.

\section{GROUPTHINK}

Having established that group decision-making is best suited for the board's functions, it needs to be kept in mind that groups themselves can be prone to cognitive biases. In the case of cohesive groups such as boards, 'groupthink' is a common danger. Irving Janis, who is credited with creating the theory, defined groupthink as follows:

A mode of thinking that people engage in when they are deeply involved in a cohesive in-group, when the members' striving for unanimity overrides their motivation to realistically appraise alternative courses of actions. ${ }^{66}$

In other words, groupthink is a form of 'concurrence seeking among members of high prestige, tightly knit, policy making groups' ${ }^{67}$ Corporate boards are high-prestige groups at the top of the corporate hierarchy and are especially susceptible to groupthink partly because boards tend to emphasise politeness and courtesy sometimes at the expense of oversight. ${ }^{68}$ Additionally, as Eisenberg pointed out, CEOs tend to appoint candidates who are not likely to 'rock the boat' and therefore generally discourage a culture of dissent. ${ }^{69}$ Further, it has been found that directors tend to appoint candidates who are more like themselves which makes the resulting group very cohesive. ${ }^{70}$ Thus board culture combined with the CEO discouraging dissent makes boards prone to groupthink - which is highly likely to impede their monitoring function.

This might explain the failure of independent directors to effectively monitor management in high profile corporate collapses during the 2008 financial crisis. According to Janis, groupthink causes groups to believe that their goals are based on ethical principles and to stop questioning the morality of their behaviour which in turn leads to over-optimism. Further, groupthink tends to cause members to ignore negative information and to view messengers of bad news as people who 'don't get it' which eventually decreases dissent. As a

\footnotetext{
${ }^{64}$ Beecher-Monas, above $\mathrm{n} 43$.

${ }^{65}$ Aaron A Dhir, Challenging Boardroom Homogeneity (Cambridge University Press, 2015), 123.

${ }^{66}$ Irving L Janis, Victims of Groupthink (Houghton Mifflin Company, 1978) 78.

${ }^{67}$ Paul't Hart, 'Irving L. Janis' Victims of Groupthink' (1991) 12(2) Political Psychology, 247.

${ }^{68}$ Jensen, above n 16, 49-50.

${ }^{69}$ Eisenberg, above $\mathrm{n} 19$.

${ }^{70}$ Mace, above n 22.
} 
consequence, members tend to feel overconfident about their decisions. In the worst cases, a group afflicted by groupthink arrives at a decision before fully evaluating the information at their disposal. ${ }^{71}$ Thus, groupthink could be disastrous in the case of corporate boards that must base decisions on their evaluation of information. However, Janis notes that groupthink is not always problematic. It could be helpful, for instance, when a group is making routine decisions given it saves time. ${ }^{72}$

Janis' groupthink theory was well-received in the social psychology literature, and is increasingly being referred to in corporate law literature after the spectacular corporate failures during and after the early $2000 \mathrm{~s} .{ }^{73}$ Case studies with respect to the Enron and WorldCom failures concluded that groupthink was largely responsible for the failures. ${ }^{74}$ Even in more recent cases, groupthink in boards is apparent. Vice Chancellor Laster in the US, identified groupthink as the most important cognitive bias that boards had to be aware of. ${ }^{75}$

Janis' theory of groupthink has generated particular interest amongst scholars studying diversity on corporate boards. ${ }^{76}$ It has been argued that race and gender diversity on the board might reduce group cohesiveness and therefore help overcome groupthink. ${ }^{77}$ However, before examining this argument, it is important to more closely examine Janis' theory. He explains the antecedents and symptoms of groupthink to help identify the phenomenon in different contexts as follows.

\section{A Antecedent Conditions of Groupthink}

According to Janis, cohesiveness of the group is the first and most important antecedent condition of groupthink. He defines cohesiveness as involving inclusive feelings that typically promote feelings of wellbeing and happiness within a group. ${ }^{78}$ While this is not always bad, too much cohesiveness may be detrimental for decision-making because members of the group tend to avoid conflict to reach a consensus quickly. ${ }^{79}$ Cohesiveness typically arises due to strong relationships among members involving an emotional tie. It is not

\footnotetext{
${ }^{71}$ Janis, above n 153, 37.

72 Ibid 37.

${ }^{73}$ See eg, Andrew Howard, 'Groupthink and Corporate Governance Reform: Changing the Formal and Informal Decision Making Processes of Boards' (2010) 20 S. California Interdisciplinary Law Journal 425; O'Connor, above n, 43; Dale A Oesterle, 'Should Courts do Behavioural Analysis of Boardroom Conduct' (2014) 9 Journal of Business \& Technology Law 51.

${ }^{74}$ M M Scharff, 'Understanding WorldCom's Accounting Fraud: Did Groupthink Play a Role?' (2005) 1 Journal of Leadership \& Organisational Studies 109; and Marlene O'Connor, above n 93.

75 Travis Laster, 'Cognitive Bias in Director Decision-Making' (2012) 20 Corporate Governance Advisor, 1, 5.

${ }^{76}$ See egs, James A Fanto, 'Justifying Board Diversity' (2011) 89 North Carolina Law Review 901; Jerry Kang, 'The Mismatch Critique: Comment on Fanto, Solan, and Darley' (2010) 89 North Carolina Law Review 937; Lisa M Fairfax, 'The Bottomline on Board Gender Diversity' (2005) Wisconsin Law Review 795; Steven A Ramirez, 'Diversity and the Boardroom' (2000) 6 Stanford Journal of Law Business \& Finance 85.

${ }^{77}$ Ibid.

78 Janis, above n $65,3-5$.

${ }^{79}$ Ibid.
} 
necessary for every member to like each other so long as they share a common goal or have strong ties to the leader, or even to a small subset of the group. ${ }^{80}$ Boards of directors, especially of large listed companies are typically cohesive bodies. ${ }^{81}$

This cohesion is a result of both the selection process for board members and the motives of directors in serving on the board. On the one hand, boards tend to select members who are similar to themselves ${ }^{82}$; and on the other, board members (including outside directors) often feel beholden to the CEO for being appointed. ${ }^{83}$ Further, directors of public corporations value their membership on boards highly because of the prestige and influence of associating with other board members. ${ }^{84}$ In the words of one board member:

It is in many ways like a club. You have a group of highly respected individuals with whom you work with. Each board I work with, has its own norms and ways of doing things. We value this ... We are conscious that being a director constitutes a unique set of roles and responsibilities. ${ }^{85}$

All of these factors combine to create cohesiveness amongst board members. Cohesiveness is further accentuated by the fact that board members tend to be culturally and intellectually similar. ${ }^{86}$ It has therefore been argued in the context of the push to populate boards with independent directors, that even if directors are financially independent, because of factors discussed above, they are not psychologically independent of the CEO. ${ }^{87}$

Two further antecedent conditions Janis sets out are: an organisation's failure to develop a proper structure with the group ${ }^{88}$; and decision-making during a provocative situational context. ${ }^{89}$ According to Janis, the probability of groupthink occurring is increased if cohesiveness is combined with at least one of the other two antecedent conditions..$^{90}$

With respect to an organisation's failure to develop proper structure within the group, Janis cites four common faults. The first is the practice of insulating the issues being discussed by the group from those outside the group. The second common fault is when the group has a strong leader who states his/her views at the outset and discourages members from taking a contrary view. The third common fault is not having established methodological procedures for gathering information and evaluating different options. The fourth fault is a lack of social, cultural and ideological diversity amongst its members which

\footnotetext{
${ }^{80}$ Ibid 211-13.

${ }^{81}$ Dallas (1996), above n 49, 6.

${ }^{82}$ Rakesh Khurana, above n 51 .

${ }^{83}$ Robert J Haft, 'Business Decisions by the New Board: Behavioural Science and Corporate Law' (1981) 80 Michigan Law Review 1, 12-13.

${ }^{84}$ Mace, above n 22, 103.

${ }^{85}$ Tom Piper, a director at many companies, including Marriot Corporation; Khurana, above $\mathrm{n}$ $139,83$.

${ }^{86}$ Ibid 105.

${ }^{87}$ Beecher-Monas, above $\mathrm{n} 43$.

${ }^{88}$ Janis, above n 65, 177.

${ }^{89}$ Ibid 258-59.

${ }^{90}$ Ibid 176-77.
} 
decreases the likelihood of group members presenting and debating different views.

The third antecedent condition refers to decision-making during a 'provocative situational context' or in other words, decision-making under stress. Again, these provocative situational contexts can be understood in terms of outside threats and threats from within..$^{91}$ In the case of a strong leader and where stress is caused by outside threats, the members of a group, would tend to quickly concur with whatever solution the leader proposes because they are desperate to alleviate their stress and cannot think of alternate solutions. Because of this tendency, there is almost no debate or analysis during the decision-making process which can ultimately lead to poor decisions. ${ }^{92}$ Other types of provocative situational context could be stress caused by inside threats which include recent failures of the decision-making group that cause members to feel personally responsible, a complex problem that might surpass the competence of the members of the group, and when the group is faced with a moral dilemma. ${ }^{93}$ Since each of these contexts might cause members to experience low self-esteem due to feelings of shame and guilt, the group members quickly move towards a consensus as a form of social support. ${ }^{94}$

Ultimately, groupthink is a defence mechanism for coping with stressful decisions within a group. However, Janis also points out that it is not necessary for every stressful situation to result in groupthink. If the leader retains an impartial and unbiased approach, groupthink can be reduced. ${ }^{95}$ This is how members sometimes rationalise unethical decisions even if each member, individually, is perceived as a moral and upstanding citizen.

While it has been established that boards tend to be highly cohesive, the other two antecedent conditions are also common for corporate boards. With respect to 'failure to develop proper structure' all four conditions are typical of many boards. First, boards of directors are often highly insular bodies with information about issues being made available to outsiders only after a decision has been made. ${ }^{96}$ Next, Janis discusses the common scenario of a leader who states his/her opinion before members have a chance to make up their minds about a given issue. This is typically seen in corporate boards since the CEO not only states the issue to be decided but also the view of the management on the matter. ${ }^{97}$ The third issue Janis discusses is the general lack of methodological procedures for gathering and evaluating decisions. However, most boards of large public-listed companies have set procedures in place for making information available to boards, getting opinions from experts, and putting the decision to vote. The final fault Janis discusses is lack of diversity in the group. This is a problem widely evident in corporate boards across jurisdictions.

\footnotetext{
${ }^{91}$ Ibid 258-59.

92 Ibid 250.

93 Ibid.

${ }^{94}$ Ibid 255, 256.

${ }^{95}$ Ibid.

${ }^{96}$ Ibid.

${ }^{97}$ Ibid.
} 
Most boards of large public companies are likely to have faced the next antecedent condition (i.e. provocative situational contexts or crisis situations) one time or another. For instance, the court in its decision in Westpac Banking Corporation v Bell Group Ltd (in liq) (no 3) ${ }^{98}$ mentions more than once the high pressure that the members of the board were facing. With respect to directors in the UK subsidiary of the company, it is noted that although Edwards and Birchmore, two non-executive directors of the UK subsidiary, had received the clearest legal advice about what was required in order to approve certain transactions, they were under tremendous pressure from the concerned banks and also the parent company to approve the said transactions. ${ }^{99}$ Despite making enquiries of the inside directors about the solvency of the company and only receiving verbal assurances unsupported by evidence in return, Edwards and Birchmore went ahead and approved the transactions. ${ }^{100}$ However, as Lee AJA, aptly points out, "while that pressure might have made the exercise of independent judgement more difficult, the duties of directors remained unaltered'. ${ }^{101}$ Thus it is important to recognise the factors that might impede board decision-making in high pressure situations and attempt to curb them.

\section{B Symptoms of Groupthink}

Janis sets out eight symptoms of groupthink. The first symptom is explained as the 'illusion of invulnerability to the main dangers that may arise from a risky action in which the group is strongly tempted to engage'. ${ }^{102}$ Each member believes that if the leader and each member of the group decides that it is okay, then the plan is bound to succeed. This is typical of groups that have been consistently successful in the past since they approve even high-risk plans based on past successes and also on the perception that the members and the leader must be lucky. ${ }^{103}$ The second symptom of groupthink is the group's belief in its inherent morality which causes decision-makers to ignore the ethical or moral consequences of their decisions because they perceive that they control the moral compass, know what everyone's best interests are, and are acting for the benefit of all. ${ }^{104}$ The third symptom of groupthink, collective rationalisation, refers to a situation where members rationalise any warning signs and proceed with risky decisions. In other words, to 'save face', groups will attempt to uphold decisions already made even if negative information comes to light that should prompt them to alter their decision. ${ }^{105}$

The next four symptoms of Janus' groupthink theory correlate with the lack of dissenting or independent views. The fourth symptom, outgroup stereotyping, refers to stereotyping of those within the group who do not concur, and to those outside the group. Outgroup stereotyping helps the dominant members within the group to believe in the correctness of their own decisions. However, the

\footnotetext{
98 [2012] WASCA 157.

${ }^{99}$ Westpac Banking Corporation v Bell Group Ltd (in liq) (no 3), 1059.

100 Ibid 2973.

${ }^{101}$ Ibid.

102 Janis, above n 65, 36.

${ }^{103}$ Ibid 35-36.

${ }^{104}$ Ibid 178.

${ }^{105}$ Ibid 86.
} 
outcasts within the group face intense social pressure. ${ }^{106}$ This explains why group members are often reluctant to voice reservations about a decision. The fifth symptom identified by Janus is the illusion of unanimity. This refers to the misconception that the entire group has arrived at a consensus. Typically, a group member who believes that the rest of the group has arrived at a consensus, wants to avoid being the last to get on board, and takes the consensus view even if he/she is not fully convinced. This results in situations where members might be too afraid to voice their concerns even if they are aware of problems with a particular decision. ${ }^{107}$ The sixth symptom is self-censorship. Like the previous symptom, this also pertains to a situation where members are hesitant to voice dissenting views because of their desire to concur with the group. Thus they would rather self-censor and remain silent or publicly agree, than raise their concerns and be treated as outcasts in the group. ${ }^{108}$ Direct pressure on dissenters, the seventh symptom named by Janis, describes how groups pressurise dissenting members. This tends to transform less powerful members into 'yes men'. ${ }^{109}$

The final symptom identified by Janus, 'self-appointed mind-guards', refers to the presence of certain members who decide voluntarily to 'protect' the rest of the group from any negative information. For instance, such a member might inform the other members that the leader is not open to criticism, or the member might notify the leader when there is even a hint of dissent from a member within the group. ${ }^{110}$

It is important to note that the different symptoms laid out by Janis are not watertight compartments, but rather factors that flow into one another. It is common to observe many, or all, such symptoms in the context of corporate boards.

\section{Groupthink and Corporate Boards-Case Studies}

Vice Chancellor Laster of the Delaware Court of Chancery, gave the example of the case In Re Southern Peru Copper Corporation Shareholder Derivative Litigation ${ }^{111}$ to discuss cognitive biases (groupthink amongst them) in the board's decision-making process. ${ }^{112}$ In that case, a special committee of the board consisting entirely of independent directors except the CEO was the decision-making body. Despite the committee's composition, in Vice Chancellor Laster's words, 'somehow, they blew it'. ${ }^{113}$ Explaining the possible reasons why the special committee 'blew it', Laster analyses the cognitive biases the members were subject to and most prominent amongst the biases was groupthink. ${ }^{114}$ For one thing, when the valuation from Goldman Sachs (expert advisors retained for the deal) was 'uncomfortable', the committee rejected it and asked Goldman Sachs to 'develop more comfortable but unconventional,

\footnotetext{
${ }^{106}$ Ibid.

${ }^{107}$ Ibid 37-38.

108 Ibid 87.

${ }^{109}$ Ibid 246.

${ }^{110}$ Ibid 88.

${ }^{111}$ In re S Peru Copper Corp. S'holder Derivative Litig, 52 A.3d 761 (Del. Ch. 2011).

${ }^{112}$ Laster, above $\mathrm{n} 74$.

113 Ibid 4.

114 Ibid 5.
} 
analyses which generated results that conformed to the Special Committee's desire to get the deal done'. ${ }^{115}$ This is clearly an example of collective rationalisation wherein the members of the committee rejected negative evidence so as to follow through with their originally intended deal price.

Further to this, Vice Chancellor Laster suggested that the special committee accepted the second opinion of Goldman Sachs (the expert advisors for the deal) which was 'clearly inscrutable'. The Vice Chancellor's opinion on why the board accepted the opinion was as follows:

I would be shocked if any director understood them. I would also be shocked if any Special Committee member raised their lack of understanding with their fellow members. I suspect what happened was that the analyses looked pretty, were presented in a nice book, and generally looked smart and official. They were accepted without any hard questioning. ${ }^{116}$

In this case, there was clearly a lack of debate or discussion which shows that the members of the special committee merely sought concurrence even if they did not understand what they were approving. Apart from purporting to understand the expert analysis, Laster also suggested that for the special committee, which had been working on the deal for a long time, failing to close the deal would seem like a loss. Instead, members chose to approve the deal despite the high risks involved, to avoid the pain of the loss. ${ }^{117}$ This again points to collective rationalisation.

Andrew Howard, in his paper discussing the import of groupthink in corporate governance reform, found that groupthink was prevalent even before the financial crisis of 2008. ${ }^{118} \mathrm{He}$ cites examples of groupthink in the technology industry during the 'dot com bubble' and the telecommunications industry in the 1990 s. ${ }^{119}$

Similarly, Marlene O'Connor analysed the functioning of the board of Enron and identified that groupthink was responsible for the board's ineffectiveness to check management behaviour. ${ }^{120}$ O'Connor found that the Enron board's cohesiveness was a result of three factors. The first factor was homogeneity amongst members. In other words, all the members were from the same social, educational and career backgrounds. This homogeneity along with extended tenures contributed to high cohesiveness. The second factor was financial incentives in terms of stock options and contributions to pet charities of board members by Enron added to the board's feelings of belonging to the elite group. The third factor was a corporate culture that promoted loyalty to the Enron senior executives, especially the CEO. ${ }^{121}$ Thus having established board cohesion, O'Conner also found the presence of the other two antecedent

\footnotetext{
${ }^{115}$ Ibid.

${ }^{116}$ Ibid $5,6$.

117 Ibid 6.

${ }^{118}$ See generally, Andrew Howard, above n 72.

${ }^{119}$ Ibid.

${ }^{120}$ See generally, O’Connor, above n 72 .

${ }^{121}$ Ibid 1263.
} 
conditions of groupthink in Enron. With respect to structural faults, one of the most important faults she named was the lack of impartial leadership on the Enron board. The CEO, Ken Lay, was also the board chair and most of the independent directors were appointed by him. Besides, the Enron board did not have a practice of meeting without the management. ${ }^{122}$ Another structural fault noted was the unquestioning acceptance of expert reports by board members. While O'Connor also mentioned problems of groupthink not just inside the board but also between the board and various gatekeepers (auditors, lawyers), that discussion is beyond the scope of this paper. ${ }^{123}$ With regard to the third antecedent condition of provocative situational contexts, O'Connor cites a number of events including the waiver of Enron's ethics codes to allow related party transactions. ${ }^{124}$

O'Connor identified many of the symptoms of groupthink in the Enron board. Enron's commercial success and the fact that it was one of the highest political donors in corporate America seemed to support feelings of invulnerability at Enron. ${ }^{125}$ Further, it is evident from some of the senate hearings O'Connor cites, that dissent was discouraged. An employee allegedly commented that anyone who 'questioned suspect deals, quickly learnt to accept assurances of outside lawyers and accountants'. ${ }^{126}$ The board's belief in its inherent morality came from the belief that they would enhance social welfare by reducing the role of government in the market. Enron's former CEO is quoted as having said, 'we're the good guys' and that they were on 'the side of angels'. ${ }^{127}$ One of the Enron board members testified that the board approved the deals in question because Enron executives were 'some of the most creative and talented people in business'. ${ }^{128}$

Collective rationalisation, or the tendency to rationalise away negative information, was another symptom found in the Enron board. One of the many examples O'Connor has cited is that board members either ignored or chose not to enquire about what the ' $\mathrm{H}$ ' stood for in the auditors' report. In fact, ' $\mathrm{H}$ ' stood for high risk and a number of transactions had been labelled as such. One director testified that he merely viewed 'high risk' as meaning 'important' ${ }^{129}$ With respect to outgroup stereotyping, O'Connor cites instances when the Enron board approved complex transactions with obvious risks and conflicts without asking questions. She attributes this to the attitude of Enron's management to label anyone (including journalists) who asked uncomfortable questions that they did not 'get it'. ${ }^{130}$ Similarly, the board's failure to ask members of management how much money they made from related party transactions points towards self-censorship. In fact, when a member of the board

\footnotetext{
${ }^{122}$ Ibid 1267.

${ }^{123}$ Ibid 1266; The role of gatekeepers in Enron's collapse has also been discussed elsewhere. See eg, John C Coffee Jr, 'What Caused Enron? A Capsule Social and Economic History of the 1990s' (2004) 89 (2) Cornell Law Review, 272.

${ }^{124} \mathrm{O}^{\prime}$ Connor, above n 72, 1269.

${ }^{125}$ Ibid 1272.

${ }^{126}$ Ibid 1266.

${ }^{127}$ Ibid 1275 .

${ }^{128}$ Ibid 1277.

${ }^{129}$ Ibid 1281.

${ }^{130}$ Ibid 1286.
} 
requested information regarding this twice but did not receive the information, he simply let the matter drop. ${ }^{131}$

\section{Board Gender Diversity as the Antidote to GROUPTHINK}

If boards are indeed susceptible to groupthink, as some of the examples discussed in the previous section show, is there an antidote or remedy for this? Many suggestions have been made of which diversity is one. Vice Chancellor Laster has suggested that boards should be educated about the phenomenon of groupthink so that they can be mindful of succumbing to its dangers. He says that while directors already know about cognitive biases, they need to be reminded. ${ }^{132}$ A solution recommended to counter groupthink has been to appoint a designated 'devil's advocate' who would have the role of arguing the opposing (possibly uncomfortable) side. ${ }^{133}$ Some have argued that the requirements for independent directors and the more recent board diversity discussion are a diluted version of the devil's advocate procedure. ${ }^{134}$

With regard to diversity, what is being sought as a remedy to groupthink is members who can offer diverse views. Beecher-Monas has suggested that diversity might provide more psychological independence than 'independent directors' as provided for by current laws. However, she cautions that neither race nor gender diversity are necessarily a proxy for viewpoint diversity. ${ }^{135}$ Considering that CEOs and nominating committees tend to select candidates who are similar to themselves, it is possible that they would select women candidates or candidates belonging to minority races who mimic white male characteristics. ${ }^{136}$ Thus, while diversity would probably help reduce the chances of a board succumbing to groupthink, it must not be merely tokenistic diversity. She suggests that diversity together with independence could result in more effective boards. ${ }^{137}$

Some interesting empirical studies have gone beyond merely checking for the effect of board diversity on firm performance which gives us a better insight into how board diversity might improve board effectiveness. In general, commentators take the view that diverse boards make better decisions because diverse board members bring diverse views. ${ }^{138}$ Studies show that educational diversity in problem-solving groups improves performance and that teams with occupational diversity solve problems faster and more effectively. ${ }^{139}$ It has been

${ }^{131}$ Ibid 1289.

${ }^{132}$ Laster, above n 74, 9.

${ }^{133}$ See generally Oesterle, above n 72 .

134 Ibid 55.

${ }^{135}$ Beecher-Monas, above n 43, 405.

${ }^{136}$ Ibid.

${ }^{137}$ Ibid.

${ }^{138}$ Elena Bajic, 'Why Companies Need to Build More Diverse Boards' Forbes (Online) August $11,2015<\mathrm{http} / / /$ www.forbes.com/sites/elenabajic/2015/08/11/why-companies-need-tobuild-more-diverse boards/\#3f19a28817ef $\$$.

${ }^{139}$ Frances Milliken and Luis Martins, 'Searching for Common Threads: Understanding the Multiple Effects of Diversity in Organisational Groups' (1996) 21 The Academy of Management Review; Sigal Barsade, et al, 'To your Heart's Content: A Model of Affective 
found that in team exercises, individuals prepare better for an exercise with a gender diverse group and that a wider range of data inputs are likely to be debated, and that the diverse group in the end is more likely to generate a better response to the problem. ${ }^{140}$

This is consistent with the views of Norwegian directors, interviewed in a qualitative study by Dhir. ${ }^{141}$ They emphasised that gender diverse boards brought diverse views and perspectives which provided a broader basis for decision-making. ${ }^{142}$ Quantitative studies also suggest that an increase in the number of female directors is associated with an amplified discussion of 'tough issues'. ${ }^{143}$ One explanation for this is that since female directors must overcome many systemic barriers to attain board positions, they tend to be highly motivated and prepared for meetings. ${ }^{144}$ Another explanation is that female directors typically come from outside the groups and networks most directors belong to, and this makes them 'outsiders', therefore giving them a different perspective. ${ }^{145}$ In support of both these explanations, a study shows that women do not shy away from the 'tough issues' in the boardroom because of what is called liminality. Liminal persons, in this context, are those in transition between 'out-group' and 'in-group' status. According to this study, since women directors have had to overcome barriers to reach board positions, they are better equipped to address difficult issues compared to male directors who are bound by 'loyalty norms'. ${ }^{146}$ The authors of this study, however, also opine that once women directors' transition into in-group, they would also be reluctant to raise difficult issues. ${ }^{147}$ Thus, insofar as liminality is responsible for women directors' effect of improved board discussion, this would be a temporary advantage.

The flip side of women directors being able to discuss tough issues is that it makes boards less cooperative. Studies have also found that homogenous boards are more cooperative and experience fewer emotional conflicts. ${ }^{148}$ However,

Diversity in Top Management Teams', 45 Administrative Science Quarterly (2000); and Patricia Pitcher and Anne Smith, 'Top Management Team Heterogeneity: Personality, Power, and Proxies', 12 Organisation Science (2000).

${ }^{140}$ Katherine Phillips et al, 'Is the Pain Worth the Gain? The Advantages and Liabilities of Agreeing with Socially Distinct Newcomers' (2009) 35 Personality and Social Psychology Bulletin 336-50 <http://psp.sagepub.com/content/35/3/336.abstract>.

${ }^{141}$ Dhir, above n 64, 15.

142 Ibid.

${ }^{143}$ Nancy McInerney-Lacombe and Diana Bilimoria Championing the Tough Issues (Catalyst Report on Directors and Boards, 2011).

144 Ibid.

${ }^{145}$ Nanette Fondas, 'Women on Boards of Directors: Gender Bias or Power Threat?', in Ronald J Burke \& Mary C Mattis (eds), Women on Corporate Boards of Directors: International Challenges and Opportunities, 172-73 (Kluwer Academic Publishers, 2000).

146 Nancy McInerney-Lacombe, Diana Bilimoria and Paul F Salipante, 'Championing the Discussion of Tough Issues: How Women Corporate Directors Contribute to Board Deliberations', in Susan Vinnicombe et al (eds) Women on Corporate Boards of Directors: International Research and Practice 123-24 (Edward Elgar Publishing, Inc, 2008).

${ }^{147}$ Ibid, 137.

${ }^{148}$ Henri Tajfel and John Turner, 'The Social Identity of Inter-Group Behaviour' in S Worchel and W Austin (eds), Psychology and Intergroup Relations (Nelson-Hall, Chicago, 2nd edn 1986); Katherine Williams and Charles O'Reilly, 'Forty Years of Diversity Research: A Review' in BM Staw and LL Cummings (eds), Research in Organisational Behaviour (JAI Press, Greenwich, CT, 1998), 77-140. 
under the monitoring model of the board, cooperation might not be as important as the ability to be able to question and assess management decisions. Thus, Beecher-Monas has argued that diversity could make board psychologically independent of the CEO because diversity in the group will make groupthink less likely. ${ }^{149}$

However, for diverse candidates to be able to contribute and make a difference to the board, it has been argued that such diverse candidates should have a 'critical mass', that is, the minimum number required to ensure that the woman/minority director does not experience the effects of tokenism. The study by Erkut, Kramer and Konrad has found that a minimum number of three women directors are required to constitute the critical mass. Only when this critical mass is reached can these women directors contribute normally, without having to face the effects of tokenism. ${ }^{150}$ A study which interviewed several women directors from Fortune 1000 companies, who were the sole woman directors of their boards, said they felt visible as lone women. One interviewee said, 'if you are alone, the spotlight is on you.' 151 The same study quotes a male $\mathrm{CEO}$ as saying that when there are three women on the board, no one woman is considered to represent an entire gender. He went to say about the three women directors on the board of his company that 'the three women don't always agree with each other, and that is healthy for the men to see ... they are independent'. ${ }^{152}$ However, a contrary conclusion was drawn in another study conducted by Broome, Conley and Krawiec, who identify a theme of interviewees saying they were comfortable being the first and only woman or minority directors on the board. ${ }^{153}$ The critical mass theory was further tested in the Norwegian context in 2011 by Torchia, Calabro and Huse who conducted a study by analysing the effect of boards with one, two, or at least three women directors on organisational innovation. They found that once the number of women directors increased 'from a few tokens (one woman, two women) to a consistent minority ('at least three women'), they are able to effectively influence the level of organisational innovation'. ${ }^{154}$

Putting these various studies and arguments together, what emerges is that diverse boards are likely to result in enhanced decision-making because diverse people would be likely to bring diverse views about the issues being considered. Further, gender diverse boards are likely to be better monitors because diversity might help counter the incidence of groupthink and to some extent because of women directors' current status as outsiders. Overall, by improving board decision-making and monitoring, board diversity can help boards function more effectively.

\footnotetext{
${ }^{149}$ Beecher-Monas, above n 43.

${ }^{150}$ Sumru Erkut, Vicki W Kramer, and Alison M Konrad, 'Critical Mass: Does the Number of Women on a Corporate Board Make a Difference?' in Women on Corporate Boards of Directors: International Research and Practice 350-66 (Susan Vinnicombe et al, eds (2008)).

${ }^{151}$ Alison M Konrad, Vicki W Kramer and Sumru Erkut, 'Critical Mass: The Impact of Three or More Women Directors', Organisational Dynamics (2008) Vol 37, No 2, pp 145, 150.

${ }^{152}$ Ibid 154.

${ }^{153}$ Broome, Conley and Krawiec, above n 59, 1060.

${ }^{154}$ Mariateresa Torchia, Andrew Calabro and Morten Huse 'Women Directors on Corporate Boards: From Tokenism to Critical Mass' (2011) 102 Journal of Business Ethics 299, 308.
} 


\section{CONCLUSION}

As the previous section sought to illustrate, gender diversity on corporate boards might help overcome groupthink so long as the women directors are also independent and bear 'outsider' status. Further, the emphasis on gender alone should not crowd out focus on other forms of diversity like race, education, tenure, professional background and other factors. Ultimately, what is being sought is members who are not part of the 'in-group' and therefore can challenge management. Thus, while gender diversity is an antidote to groupthink, other forms of diversity are significant as well. It is therefore necessary that further research regarding board diversity is expanded to include a focus on other forms of diversity. Conducting and disseminating such research will better educate companies and shareholders about the importance of board diversity.

Based on the dominant theories informing corporate law, this paper has identified the primary role of the board to be that of monitoring. Through an historical analysis, this paper has also found that regulations about the composition of the board of directors were aimed at ensuring that the resulting board could effectively monitor management. Thus, most boards of directors were populated with independent directors in most Anglo-American countries. However, an examination of high profile corporate failures like Enron, WorldCom, and even the Bell Group in Australia, reveals that independent directors alone would not make boards effective monitors. The theory of groupthink formulated by Janis was examined to understand how it might explain the failure of independent directors on corporate boards to ensure effective monitoring of management. Since the application of this theory to corporate law is still in its infancy, this article has explored in detail the application of this theory by legal scholars in the context of the board of directors. Ultimately, lack of diversity being one of the antecedent conditions of groupthink, it is not very surprising that diversity is being suggested as a powerful means to counter groupthink. Board diversity could well improve a board's monitoring abilities by countering groupthink and thus ensuring that it performs its functions more effectively. 